\title{
الإحالة وتطبيقاتها في سورة الروم
}

\section{د. علي مجدي علاوي}

الجامعة المستنصرية / كلية التربية الاساسية علجية علوية

المقدمة :

الحمد الله الذي علّم الإنسان ما لم يعلم ، وأثنهد أن لا إله إلا الهه وحده لا شريك له وأثنهد انٍّ محمداً عبده ورسوله ، أرسله بالهُى ودين الحق فهو خير من عُلَِ وعَلم فختم بـه النبوة والرسالة فكان مبلِّنا لشريعته بأكمل بيان وأحسن تعليم .. فصـلاة بـي وسـلامه عليه وعلى آله وأصحابه الطيبين الطـاهرين .. الذين أمنوا به وعزّروه ونصروه واتبعوا النور الذي أنزل معه ، وبعد .. فإنٍ أفضل ما صُرفت فيه أوقات العباد

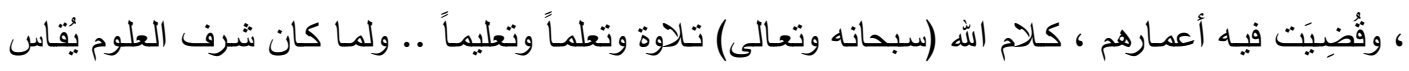
بشرف موضوعاتها .. فإنَّ الدراسات القرآنيـة تعد اثرف العلوم لارتباطها بكتاب اله الكريم .. لذا فقد جاء أسلوب القرآن متتوع وطرقه متعددة من أجل أن نلائم أحوال الناس على اختلاف افهامهم وعقولهم .. وما طُبِحَت عليه نفوسهم من تباين في التكوين والاستعداد .. أو في الثقافة والتفكير .. ومن أجل تحقق مقاصده

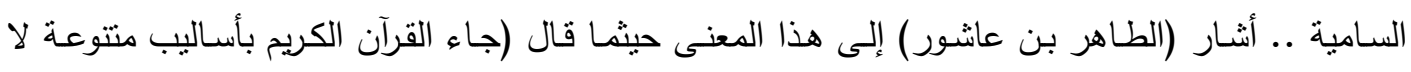
يحول دونها ودون فهمها حائل .. ولا يغـادر مسلكا إلى ناحية من نواحي تقويم السلوك الإنسـاني الا بيّنه

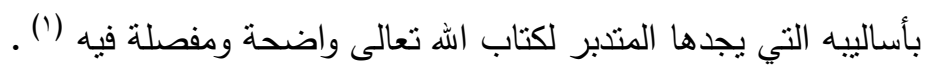

ومـن هذه الأسـاليب التي وردت في كتاب الهه (سبحانه وتعـالى) أسـلوب الإحالـة الذي يعد مـن الاسـاليب التي تكسب الكلام قوة في المعنى ، وزيادة إبداع النظم في آيات القرآن الكريم ، وهذا الأسلوب

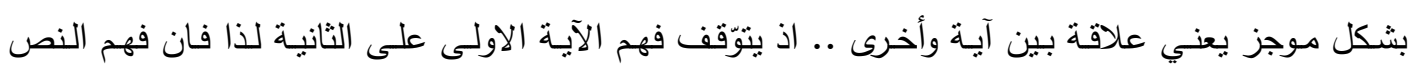
يقتضي ان نبحث كمخاطبين في مكان اخر داخل النص أو خارجه (؟) .

لذا تُعد الإحالة من أهمّ وسائل الاتساق والانسجام اللُّنوي .. وهي معيار من المعايير التي تسهم في إيصـال المعنى المـراد للقارئ .. فهي وسبيلة من أهّم وسـائل سبك العبـارات لفظيـاً مـن دون إهمـال ترابط الالالات الكامنة التي تحتملها .. فهي صياغة أكبر قدر من المعلومات بأنفاق أقل قدر ممكن من الوسائل ، 


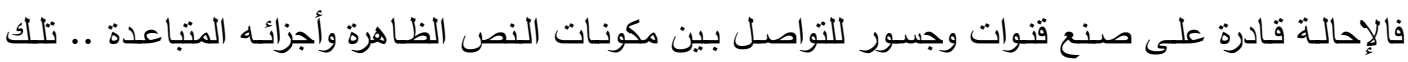

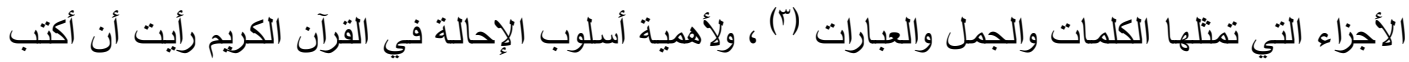

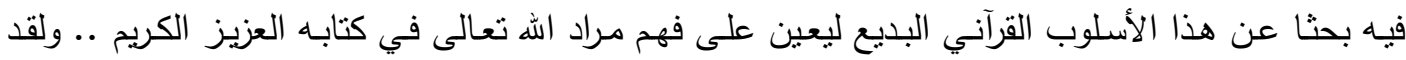

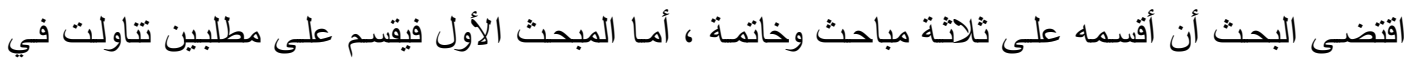

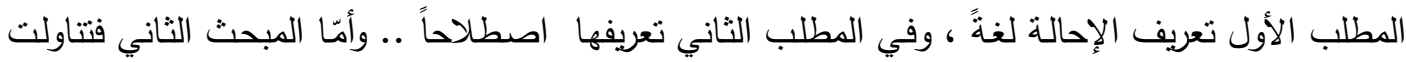

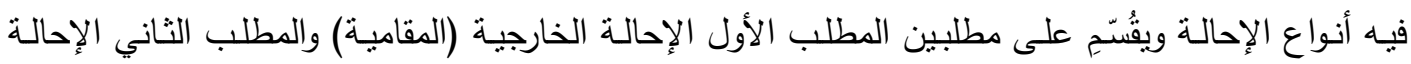

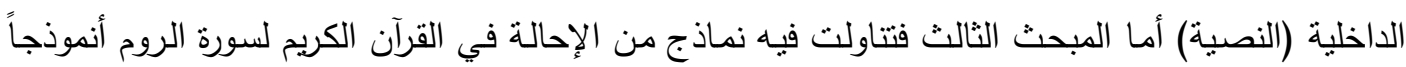

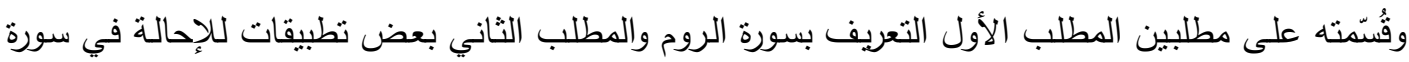

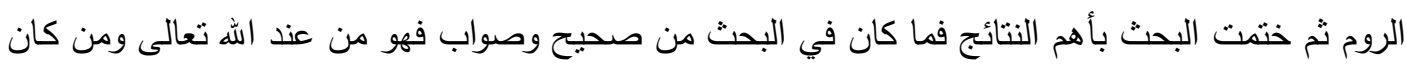

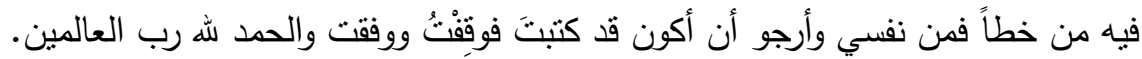




\section{المبحث الاول}

\section{تعريف الإحالة لغة واصطلاها}

المطلب الاول تعريف الإحالة لغة :

الإحالة لغة : تأتي الإحالة في اللغة بمعان عديدة بمكن ، إيجازها فيما يلي :

أولاً: التحَّول : يُقال أحال الرجل إحالة إذ تحول من شيء إلى شيء آخر (๕)، والتحول التتقل من موضع

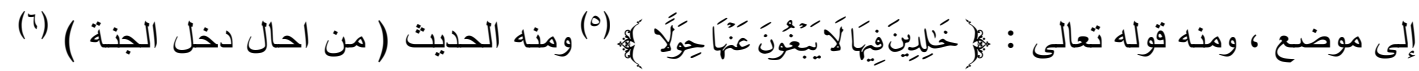

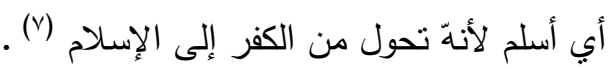

ثُانبا: بمعنى السئنة : والحول سنةٌ بأسرها والجمع أحوال ويُقال أحال الثيء حولا ولو مّر عليه حولا كامل أي

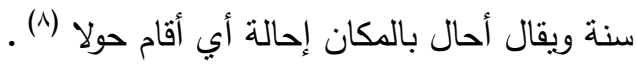

ثالثا: بمعنى المحال : يقال أحال الرجل : أتي بالمحال وتكلم به (9) .

لريعا: بمعنى صب الماء : يقال أحال الماء من الدلو : أي صبه (·').

خامسا: بمعنى الصرف : يقال وأحال الغريم بدينه على آخر إذ صرفه عنه الله فهو (محيل) والغريم (محال)

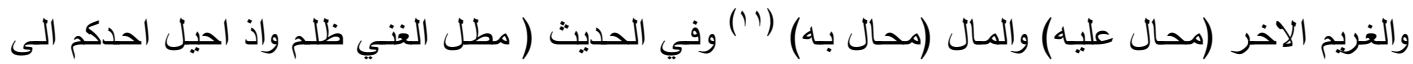

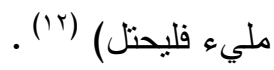

المطلب الثاني تعريف الإحالة اصطلاحاً :

حاولت عبارات الباحثين المحدثين تبيين حقيقة معنى الإحالة اصطلاحاً وذلك بحثناً منهم عن تعريف جامع مانع من هذه التعاريف ما يأتي : تعريف (سامي عياد) عرفها باّنها ( إثارة نحوية لشيء سبق ذكره ) (r') . 
ويعرفها (انس بن محمود) إلى أن الإحالة : "علاقة معنوية بين ألفاظ معينة وما نتشير إليه من أثياء أو

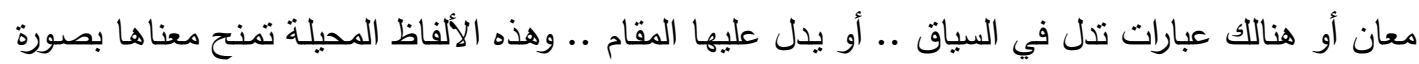

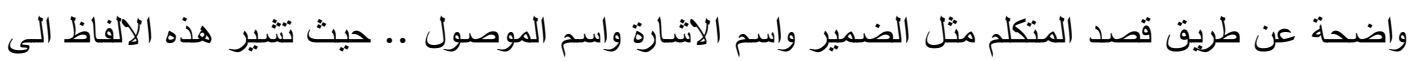

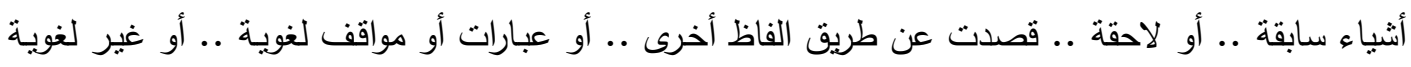

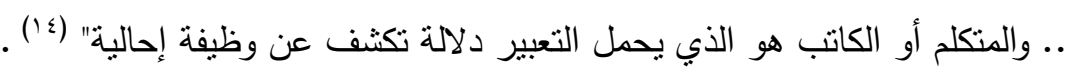

والمتأمل في هذه التعاريف يجد التباين في الالفاظ للالالة على المعنى المراد ففي تعريف (سامي

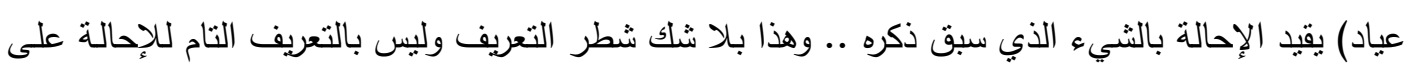

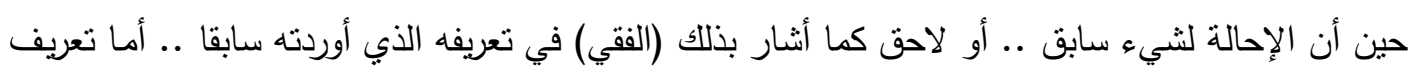

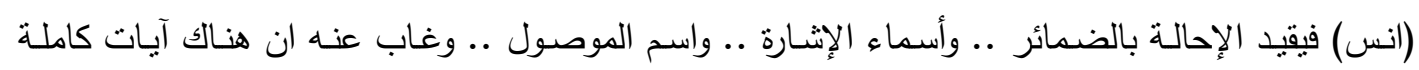

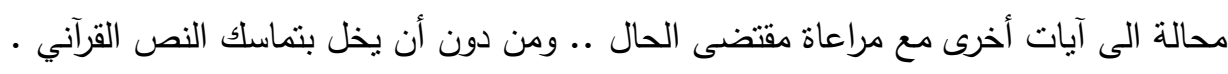

\section{المبحث الثاني}

\section{أنواع الاحالة}

لقد بين لنا القرآن الكريم بما لا يقبل الثنك ، إن في أسلوبه أنواع من الإحالة دلت عليه أنواع من

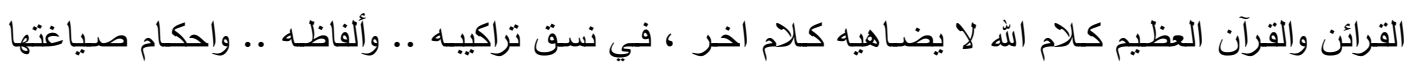

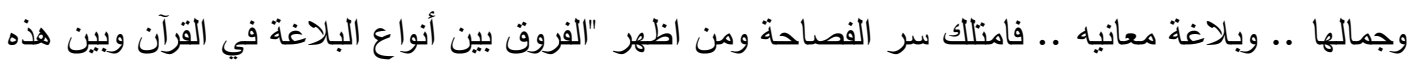

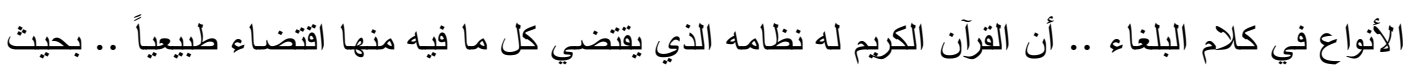

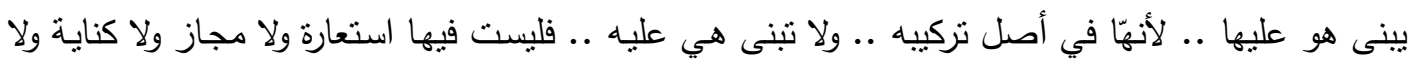

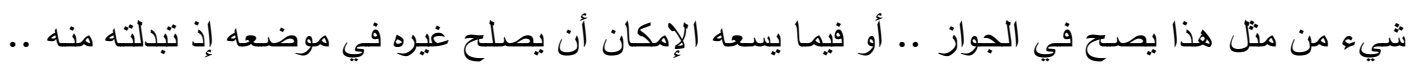

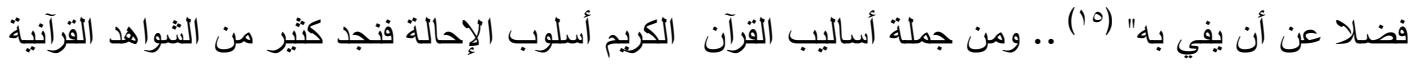

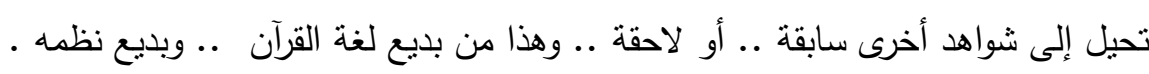

وللعلماء تقسيم نافع في أنواع الإحالة وأقسامها فهم يقسمونها على نوعين .. الاولى إحالة خارجية

. . والثانية داخلية (1') .. وسأوضح عن هذين النوعين بشيء مصحوباً بالأمتلة .. والثواهد القرآنية . 


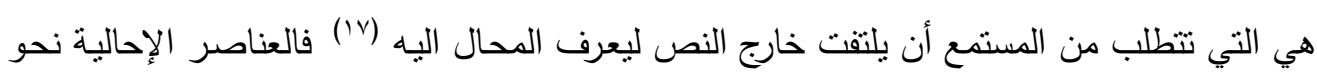

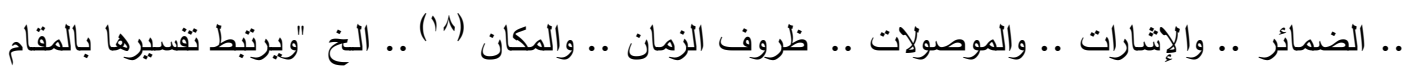

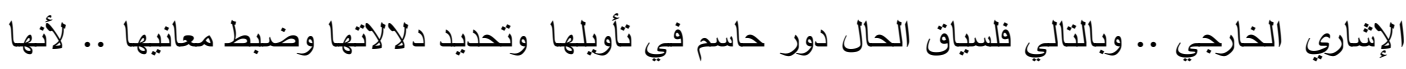

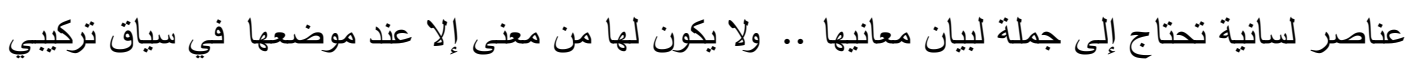
، فحينئذ تفسر في إطار بنية النص .. أو في بنية السياق المقامي"(9.") .

ويذكر (الأزهر الزناد) في حده للإحالة المقامية إلى ما هو خارج اللغة بأنها "إحالة عنصر لغوي

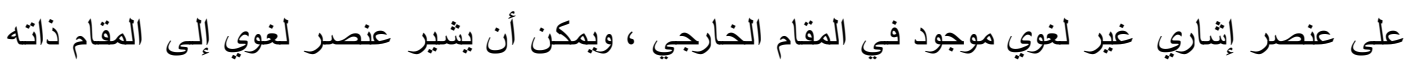

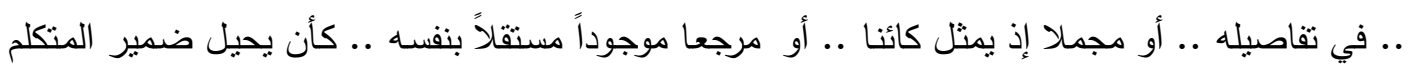

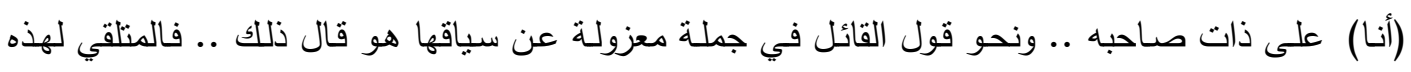

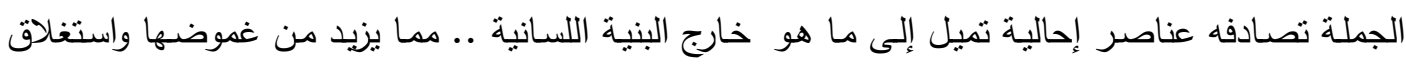

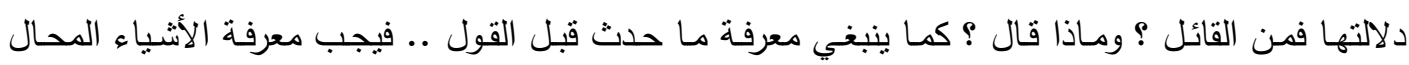

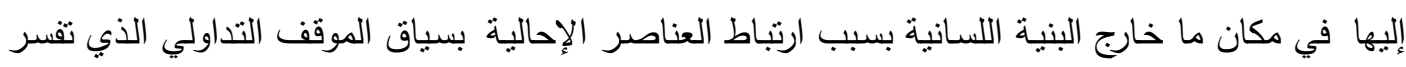
في ضوئه تلك العناصر الإحالية" (r.).

فالإحالة الخارجية علاقة موجودة بين نص أو بعض عناصره وبين السياق الخارجي ، وهذا يوجه إلى الى

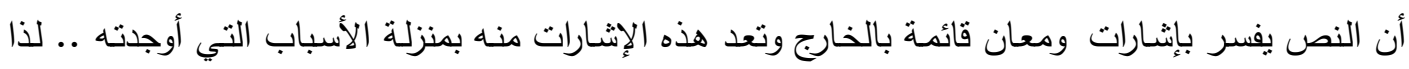

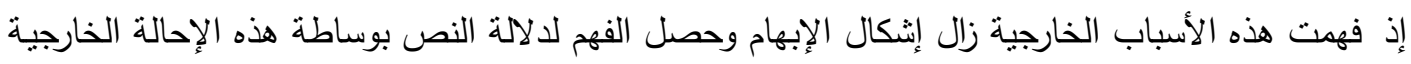

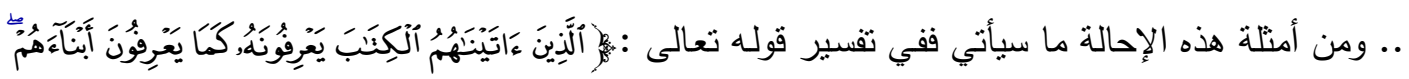

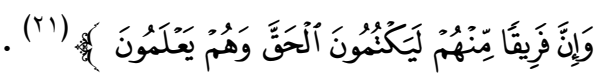

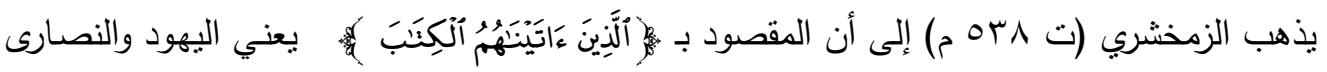

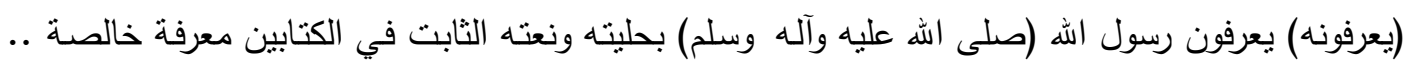

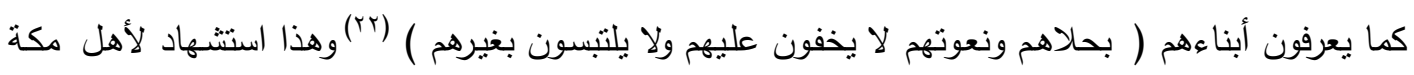


بمعرفة أهل الكتاب به وبصحة نبوءته حيث يقرر رجوع الضمير (هم) إلى اليهود والنصارى الذين لم يجر الئه

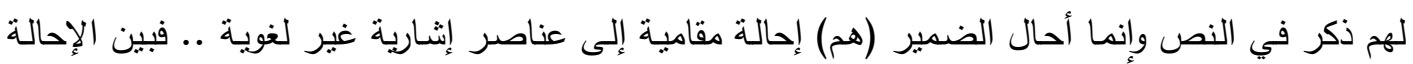

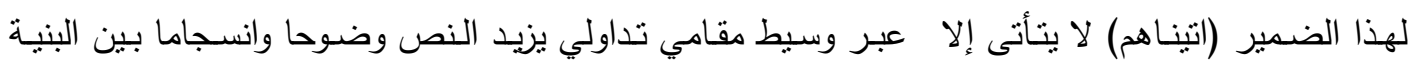

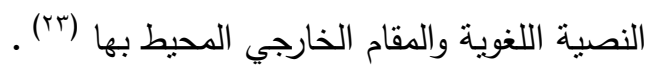

ومما يؤكد هذا النوع من الإحالة (القرطبي ، ت: التT هـ) ودور السياق في إزالة اللبس بتعيين

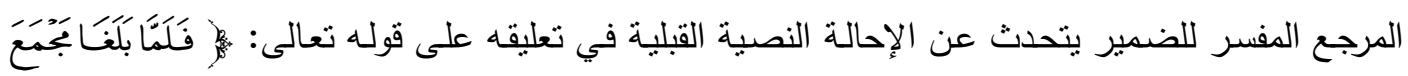

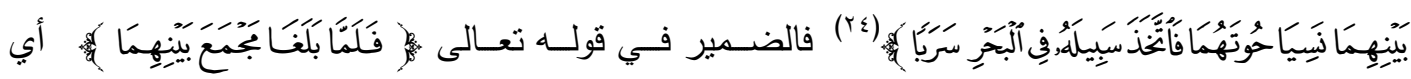

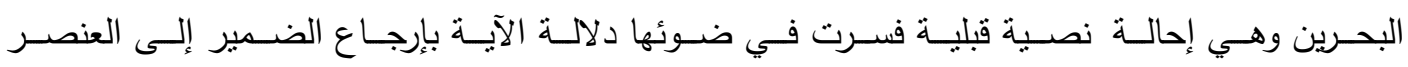
الإثناري الدذكور سابقا له (مجمع البحرين) (ro) .

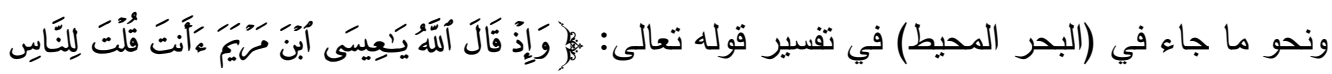

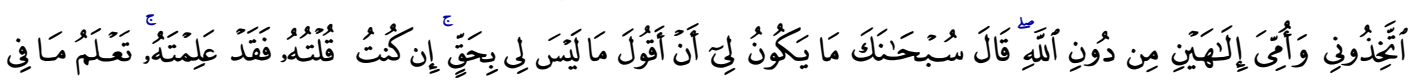

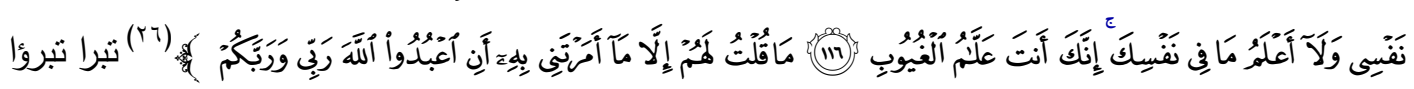

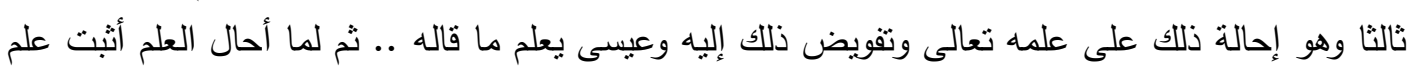

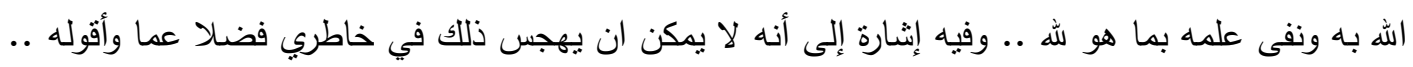

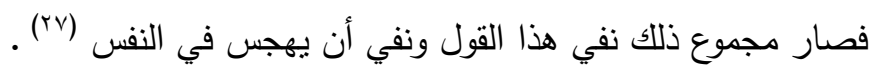

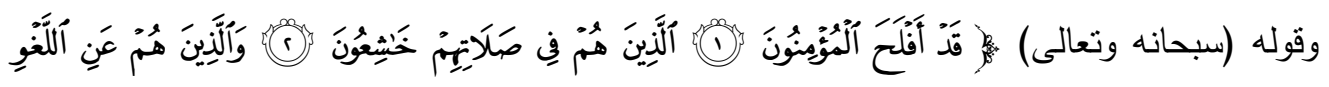

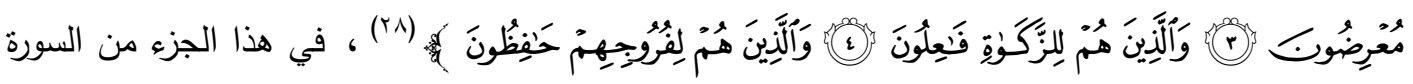

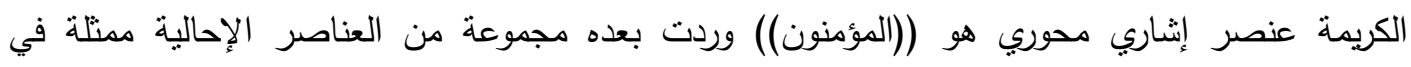

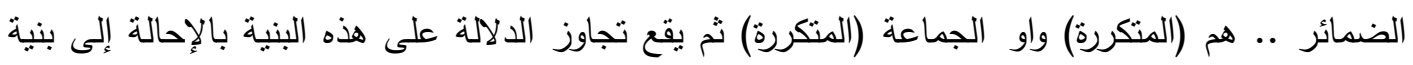

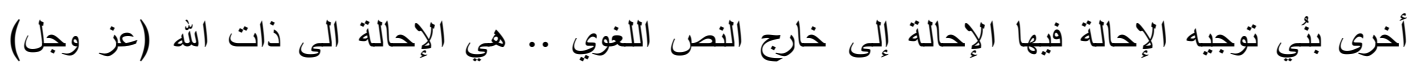

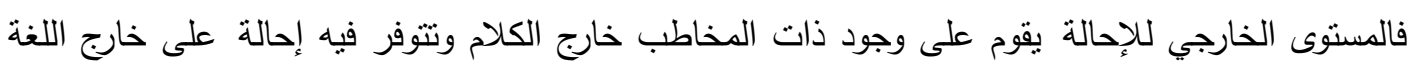


ويتضح من الإحالة الخارجية أن ثمة علاقة واضحة بين اللغة والموقف ، فالموقف يؤثز بقوة في

استعمال اللغة ونوع المفردات والأسلوب المناسب لنوع الموقف المراد الحديث عنه أو وصفه .

\section{المطلب الثاني : الإحالة الداخلية ( النصية ) :}

لقد أكدت الآيات القرآنية بجملتها انها ذات علاقة متماسكة من حيث التركيب الرباني البديع والنظم الفريد بحيث يمكننا القول إن الإحالة الداخلية هي .. العلاقات الإحالية داخل النص بحيث ترتبط العناصر الإحالية بالعناصر الإثارية النصية أثناء سياقها في التركيب اللغوي (·r) وبذلك فهي إحالة على العناصر اللغوية الواردة في الملفوظ سابقه .. أو لاحقه .. فهي نصية والإحالة الداخلية هو مصطلح استخدمه بعض الإل اللغوبين للإثـارة إلى علاقات التماسك التي تشاعد على تحديد تركيب النص (ا⿳r)، وبناء على ذلك نعالج الإحالة الداخلية بدراسة نوعيها وهما :

أ- - الإحالــة الاخليــة القبليــة : هـي اسـتخدام كلمـة أو مفـردة تشـير إلـى كلمـة أخـرى أو مفـردة

أخرى سابقة في النص (rr)، وهي الإشـارة إلى ما سبق من ناحية .. والتعويض عنه بالضمير .. أو بالتكرار .. أو بالتوابع .. أو بالحذف من ناحية اخرى .. ومن ثم الإسهام في تحقيق التماسك الإسك النصـي من ناحيـة ثالثة... والإحالة القبليـة إلى سـابق.. أو متقدم تتم حين تحيل صيغة الإحالة

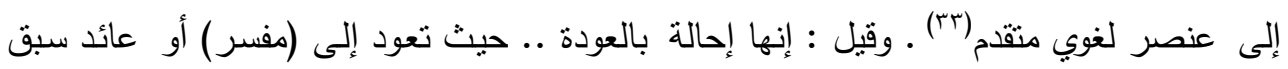
التلفظ بـه ومنهـا يجري تعـويض لفظ المفسر الذي كان لـه مـن المفـروض أن يظهر حيث يـرد المضـمر .. فالمفسر أو الثـاهد يشـار إلبـه اولا ثم يعـاد ذكره في صـورة بنيـة مضـمرة تحيل إلبـه

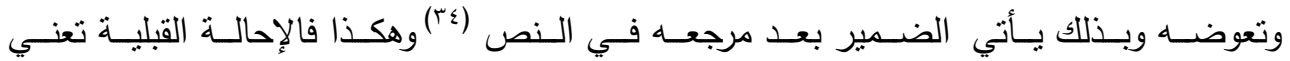
إحالة عناصر لسانية واردة في الملفوظ ذات سمة إحالة إلى عنصر إثـاري سبق التلفظ بـه سابقا

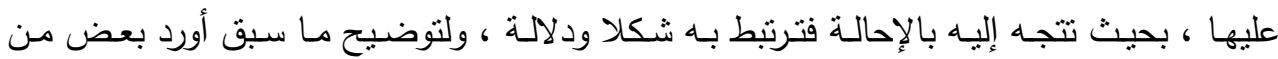

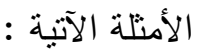




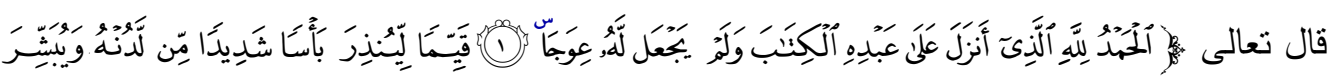

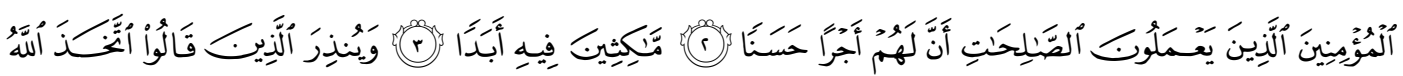

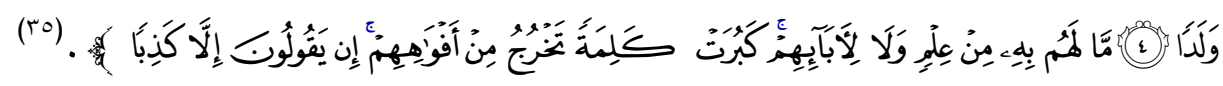

نلاحظ في بداية الآيات ورود لفظ الجلالة ((اله)) كعنصر اشـاري يفيد كل المحيلات اللاحقة عليه

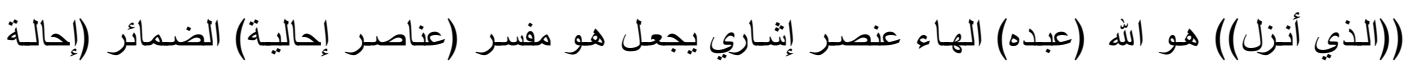

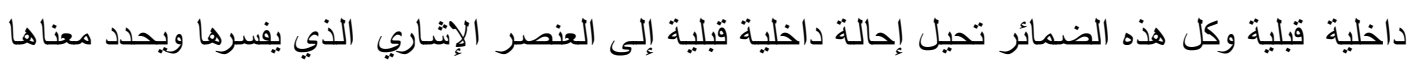

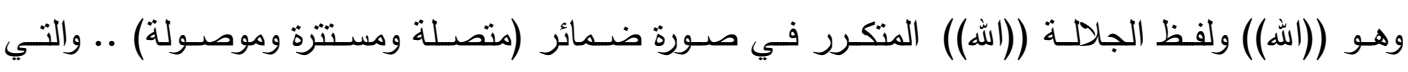
تقوم على حضوره وإستمراره على إمتداد طول النص القرآني لم برد في موضع الحاجة إليه بعد امتصاصها

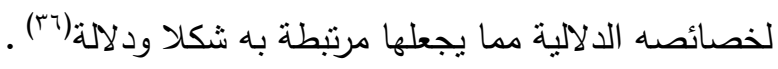

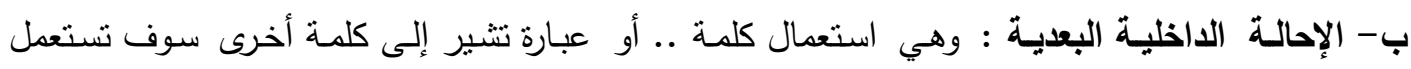

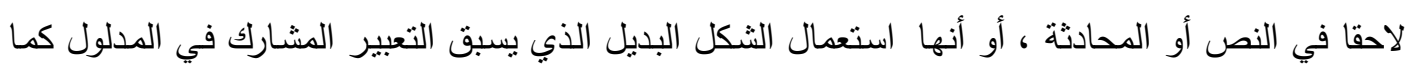

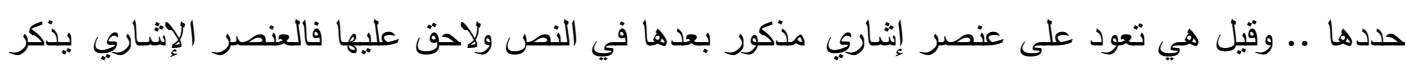
بعد العنصر الإحالي ويأتي لاحقا عليه (نr) .

فالإحالة البعدية إذن تعني ورود العنصر الإحالي قبل مرجعه ومفسره الذي يعود عليه ويحيل إليه .. وهي عكس الإحالة القبلية وسنوضحها في الأمثلة الآتية :

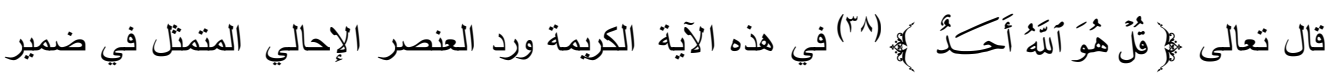

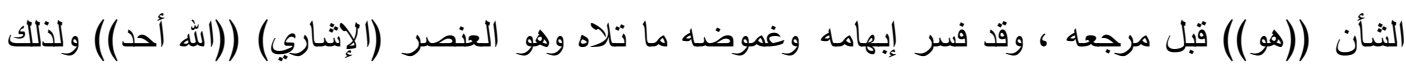

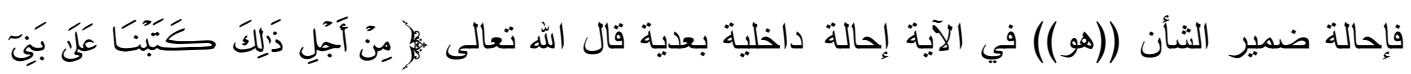

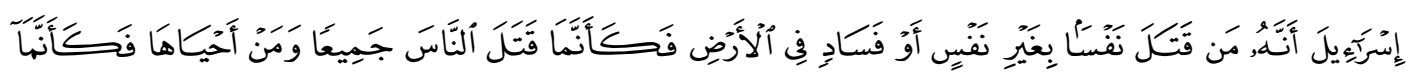

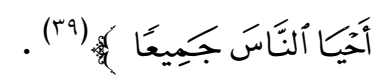

\section{المبحث الثالث}




\section{بعض تطبيقات الإحالة في سورة الروم}

السور القرآنية المباركة امتازت بخصائص ربانية فكل سورة لها إيقاع خاص بها من حيث .. تركيب

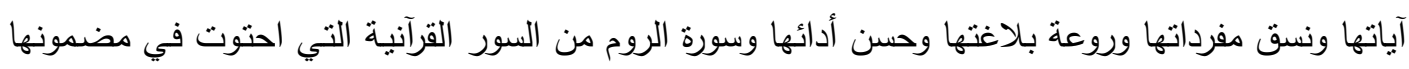

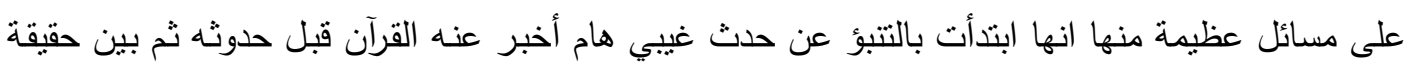
المعركة بين حزب الرحمن وحزب الثيطان فقد ساقت الآيات شواهد ودلائل على إنتصار الحق على على على الباطل

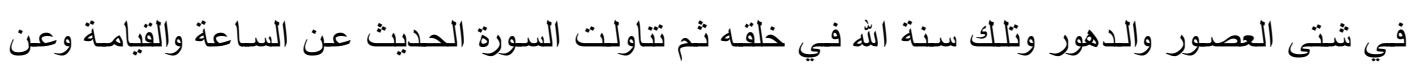

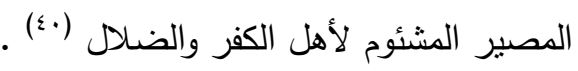

ثم تتاولت بعض من الدلاثل الغيبية والمشاهد الكونية الناطقة بقدرة الهه ووحدانيته لإقامة البراهين

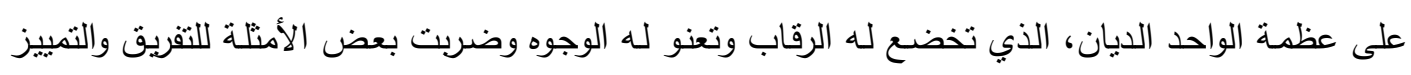

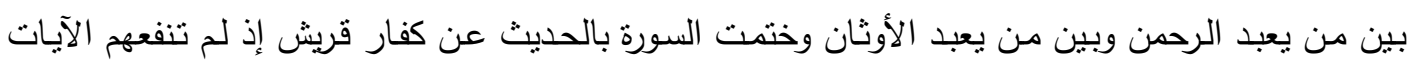

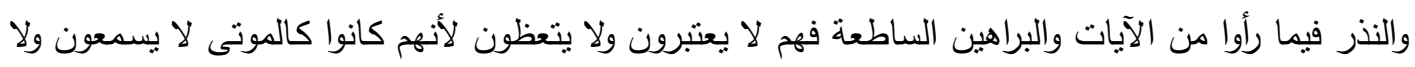

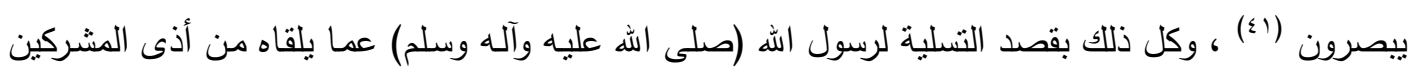

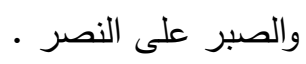

\section{المطاب الاول التعريف بالسورة :}

إلغا- سبب التسمية : ne

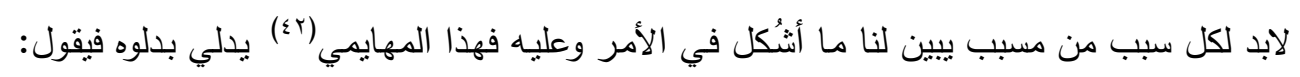

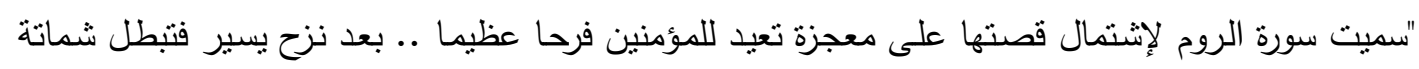

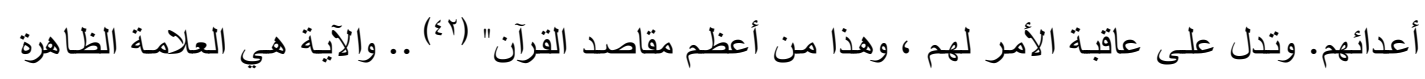

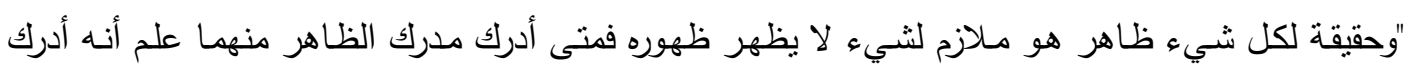

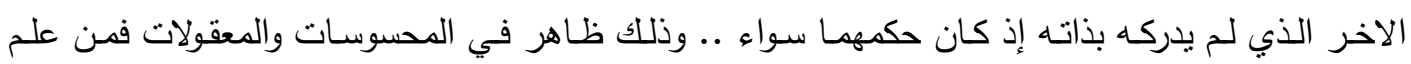
ملازمة العلم للطريق المنهج ثم وجد العلم علم أنه وجد الطريق وكذا إذ علم شيئا مصنوعا علم أنه لا بد لـ له له

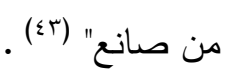


إن لسور القرآن مكاناً للنزول وأهدافاً على كل من ينطرق إلى تفسير كتاب اله أن يقف عندها ليعرف ألى ألفا

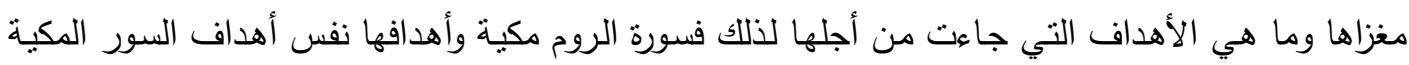

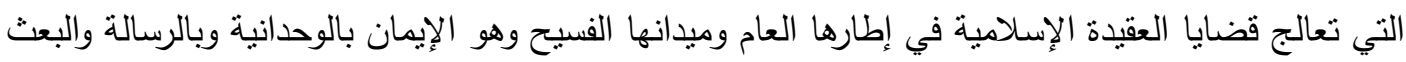

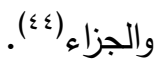

ثالثا- ماذا ضمت سورة الروم من محاور : ضمت سورة الروم المباركة محورين هما :

المحسور الاول : الكثـف عن الأواصـر الوثثقـة بـين أحوال النـاس .. وأحداث الحيـاة ، وماضـي البشـرية

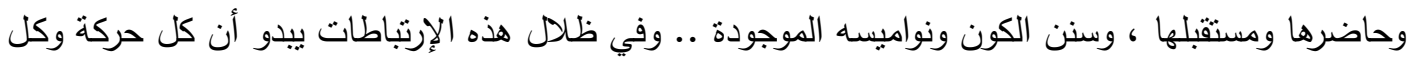

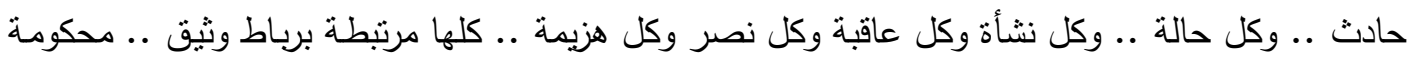

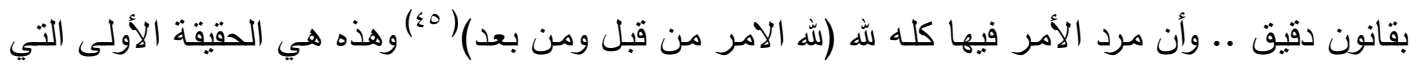
يؤكدها القرآن كله.. بوصفها الحقيقة الموجهة في هذه العقيدة( هَ).

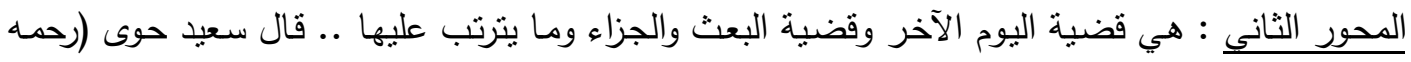

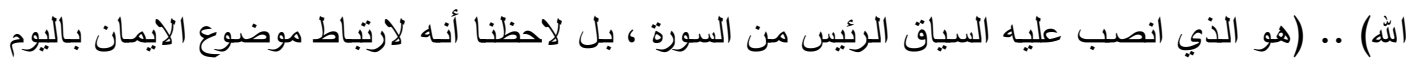

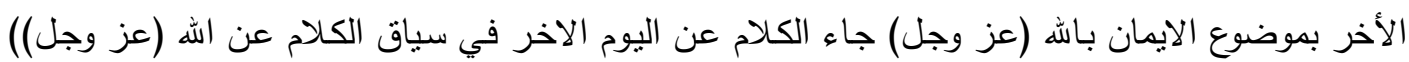

وعلى أسـاس هذين الدحورين يمكن تقسيم السورة إلى خمسـة مقاطع مبتداً من الحروف المقطعة ((الم))

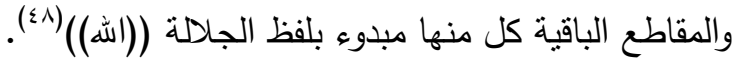

أما بالنسبة إلى المقطع الأول يبدأ من الآية الأولى وحتى نهاية الآية العانشرة تحدثت هذه الآيات

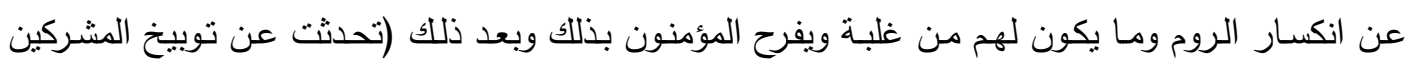

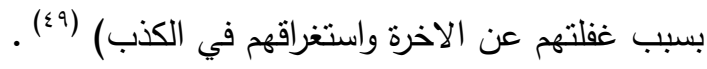


أما المقطع الثاني فيبدا من الآيـة (1) حتى نهاية الآية (9) فقد تحدثت هذه الآيات عن يوم

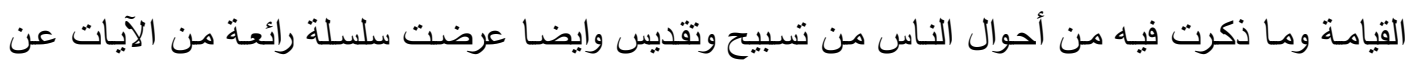

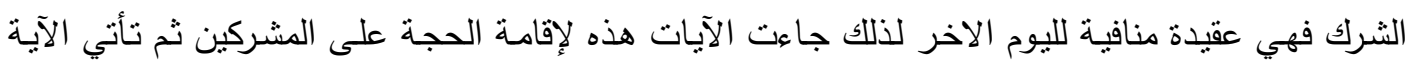

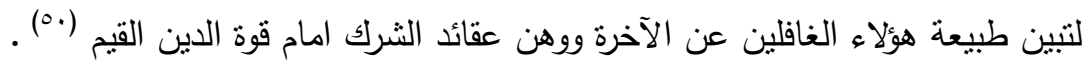

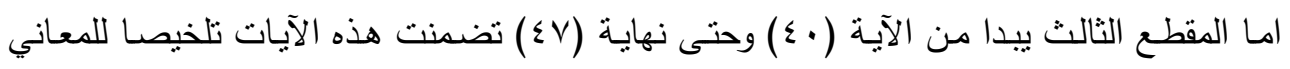

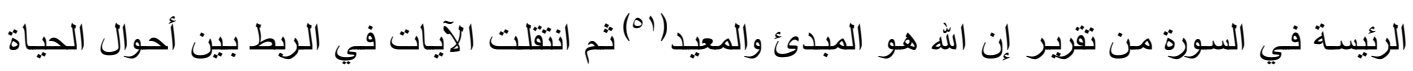

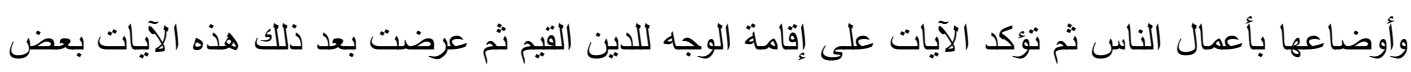

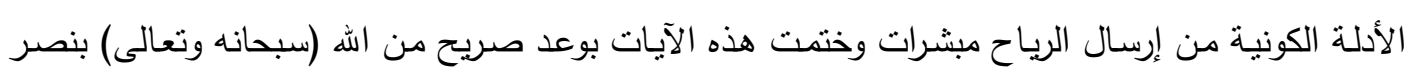

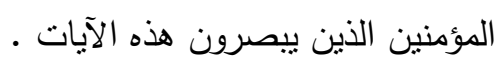

المقطع الرابع يبدأ من الآية (1) إلى نهاية الآية (به) فالآيات في هذا المقطع تكمل هذا الترابط

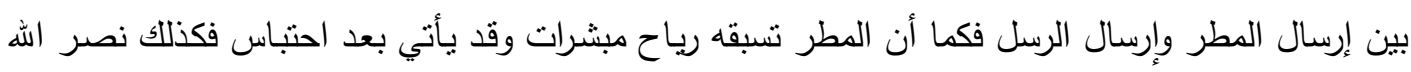

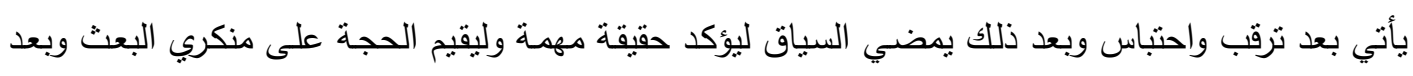

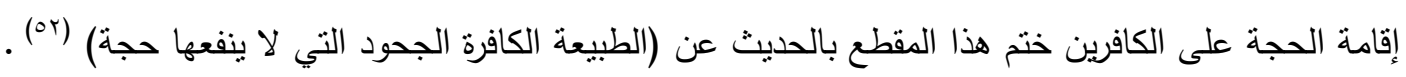
المطلب الثاني : نماذج من الإحالة الى سورة الروم انموذجاً : هذه بعض الآيات القرآنية التي لها علاقة مع الآيات الأخرى يمكنني أن أوردها على النحو الآتي :

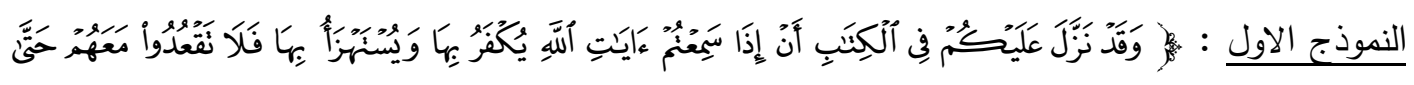

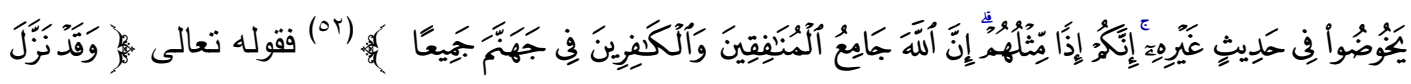

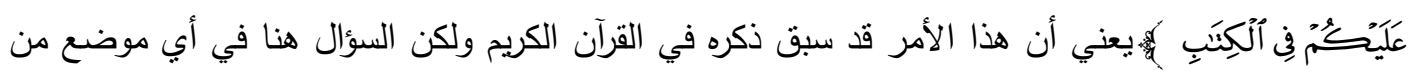

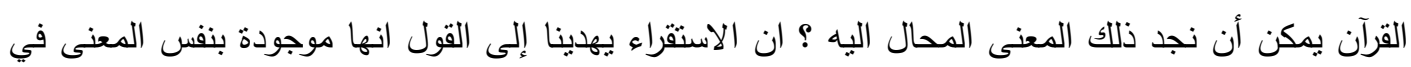

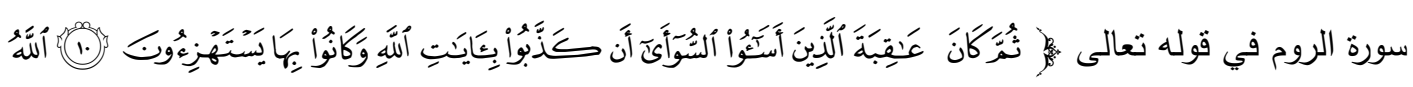

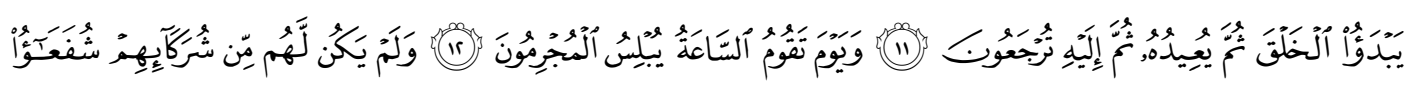




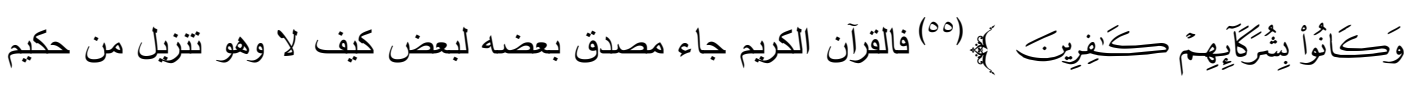
خبير ، فهو يخاطب العقل بالبرهان .. والجنان بالبيان .. فهو يفسر بعضه البعض الآخر من جانب مهر من جوانبه التفسيرية .

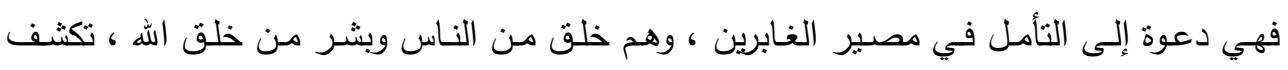

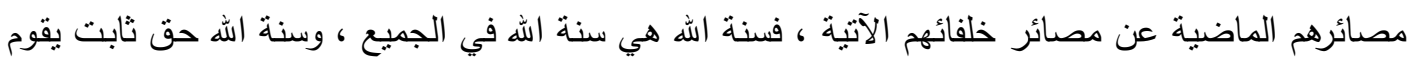

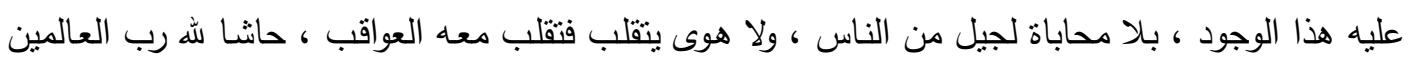
، فهي دعوة إلى إدراك حقيقة هذه الحياة وروابطها على مدار الزمان وحقيقة هذه الإنسانية الموحدة المنشأ

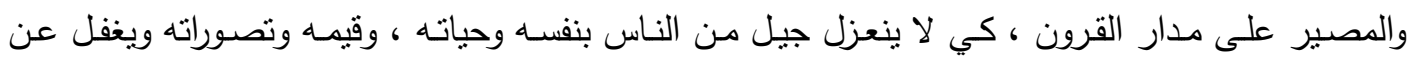

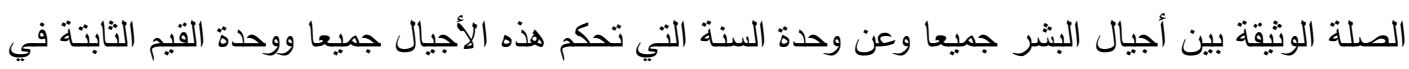

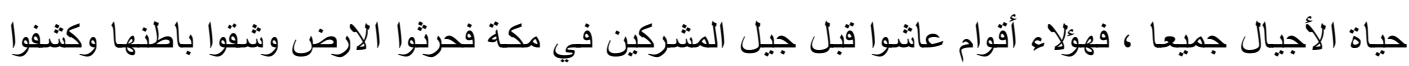

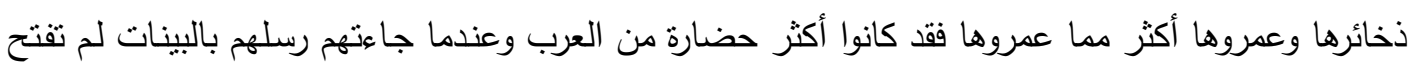

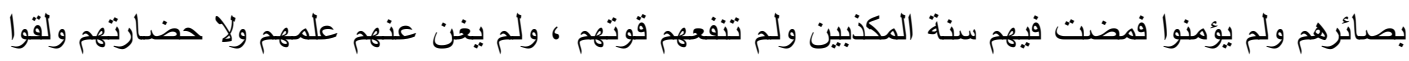

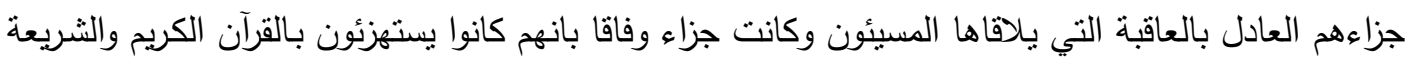

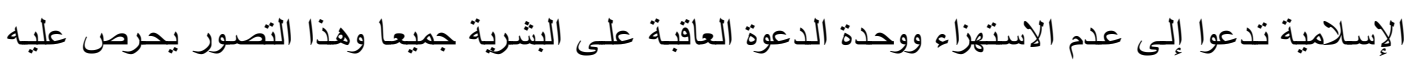
الإسلام لبطبع في قلب المؤمن وعقله (10) .

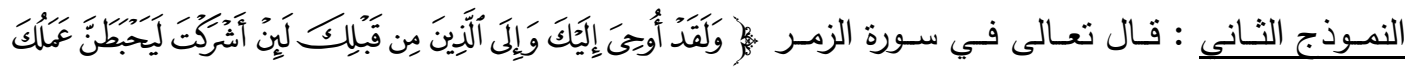

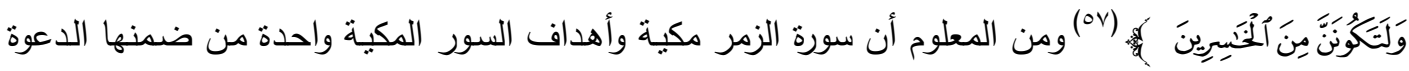

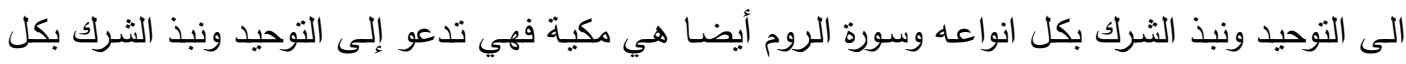

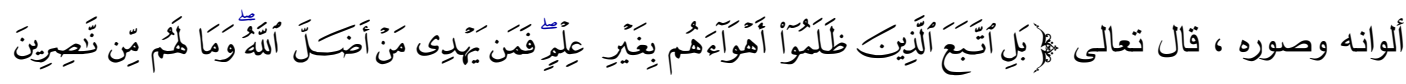

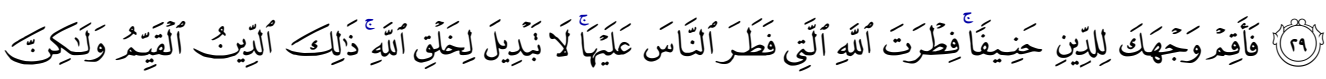

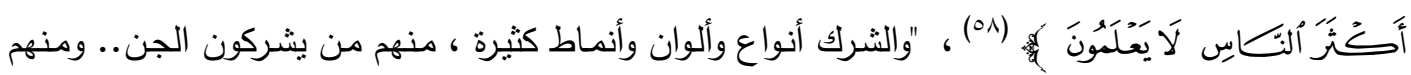

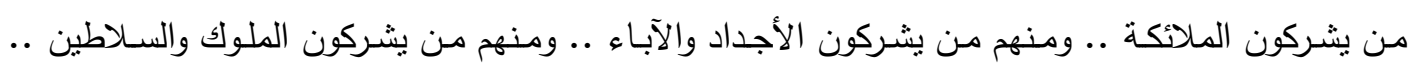

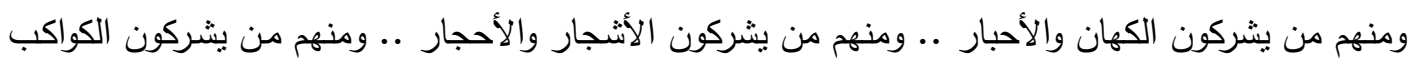


والنجوم .. ومنهم من يشركون النار .. ومنهم من يشركون الليل والنهار .. ومنهم من يشركون القيم الزائفة والرغائب والأطماع ، ولا ينتهي انماط الثرك وأثكاله" (09) .

الفطرة السليمة هي الفطرة التي فطر اله الناس عليها فهي توجيه لإقامة الدين الحنيف، فهو سلطان

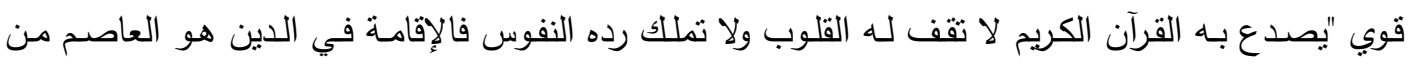

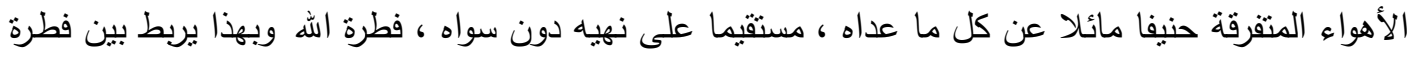

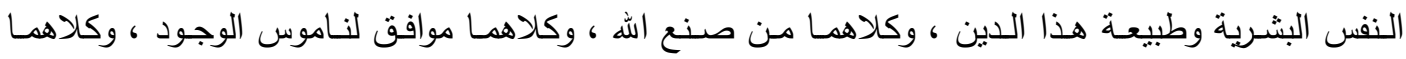

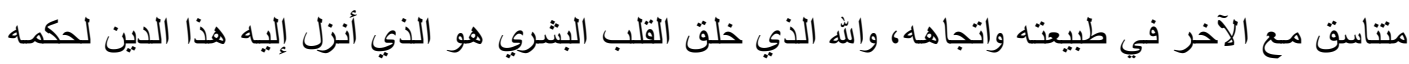

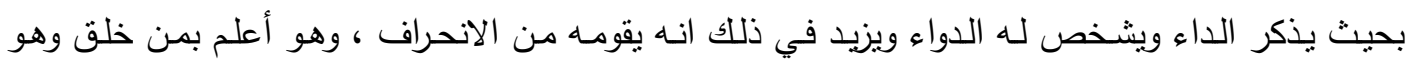

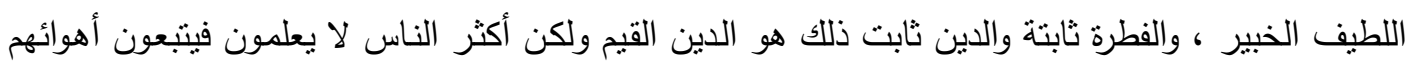

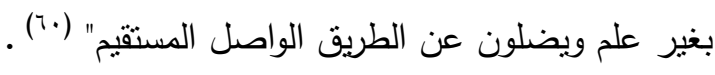

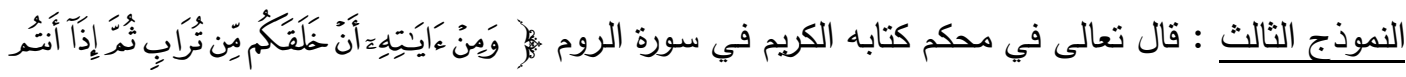

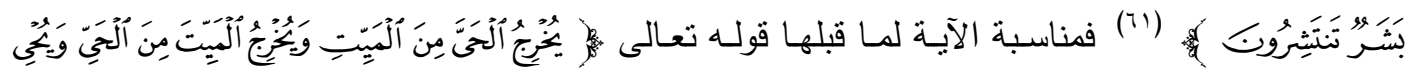

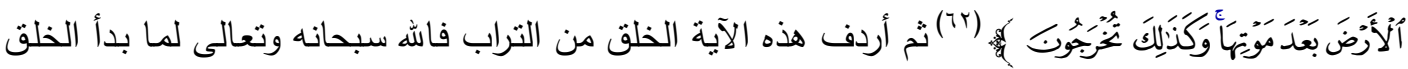

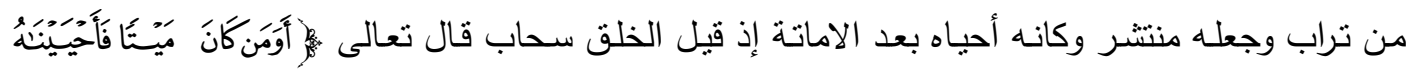

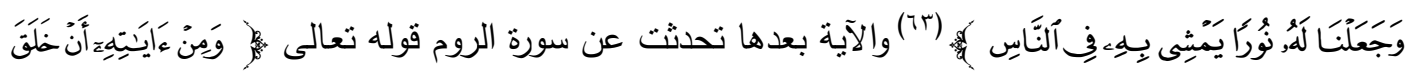

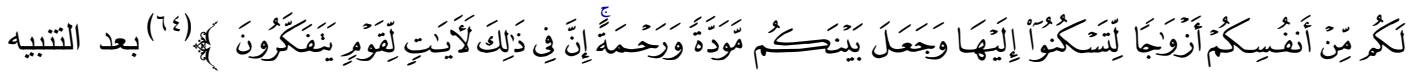

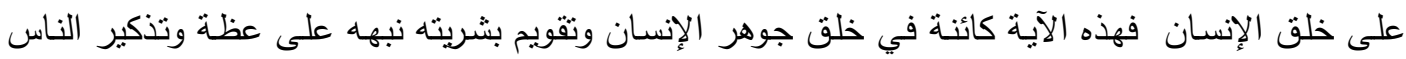

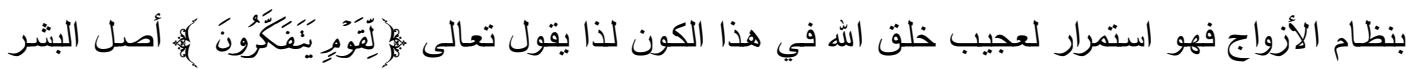
"من تراب ثم من ماء مهين ثم تصور فكان علقة ثم مضغة ثم صار عظاما شكله على شكل إنسان ثم العظام

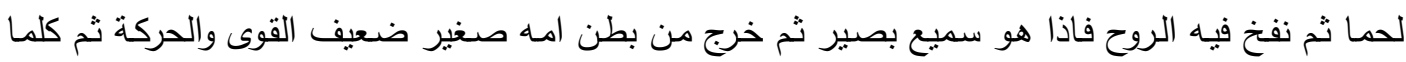

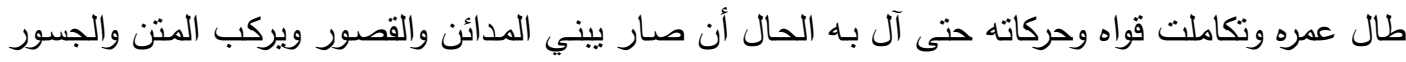
فسبحان من خلقهم وسيرهم وسخرهم وصرفهم إلى المعايش والمكاسب وفاوت بينهم وبين العلوم والفكر "(10).

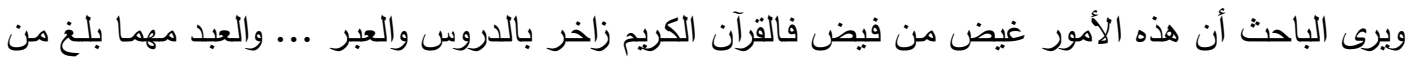


درجة فهم والادراك ما بلغ معشار ما أودع اله في محكم كتابه العزيز فسبحان من قال (الحمد لله الذي أنزل

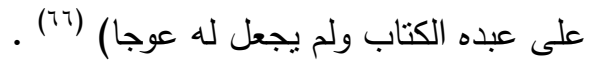


الحمد لله رب العالمين الذي أعانني ويسر لي إكمال البحث ويسر لي خاتمته فله الحمد في الأولى والآخرة حمدا يليق بجلال وجهه وعظيم سلطانه شكرا يوافي نعمه وثثاء كما أثنى على نفسه ، في خاتمـة البحث توصلت إلى مجموعة من النتائج تم تلخيصها فيما يلي :

1- ان القرآن لم يغفل عن اسلوب الإحالة فأحاط بـه واستخدمه للإثـارة إلى أن القرآن كتاب فيه من

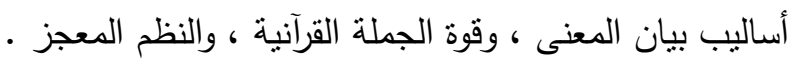

r- الإحالة في اللغة لها معان عدة منها .. التحول والسنة والإقامة في المكان ، وصب الماء . ب- - اما الإحالة في المعنى الاصطلاحي فهو اسلوب في النص يقتضي الرجوع إلى ما سبق أو إلى ما

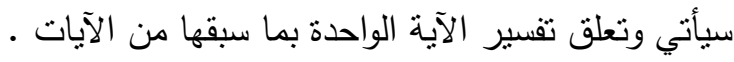

ع- - للعلماء تقسيم نافع لأنواع الإحالة فيقسموها على نوعين الإحالة الخارجية والإحالة الداخلية . 0- ان لسورة الروم منزلة رفيعة جاءت بها الأحاديث النبوية لفضلها ومكانتها من بين السور فهي مكية

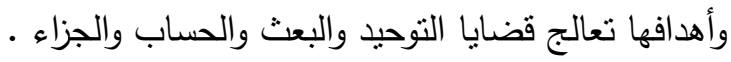

צ- ان ألفاظ الإحالة في الآيات التي احيلت إلى سورة الروم في بحثي هذا هي ((نزل عليكم في

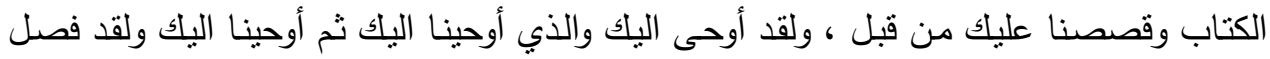

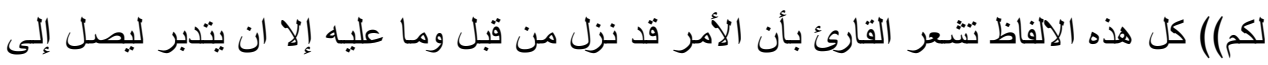

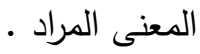

1. التحرير والتتوير ، محمد الطاهر بن عاشور ، الدار التونسية للنشر ، ـ191 ، 10/•؛ . 


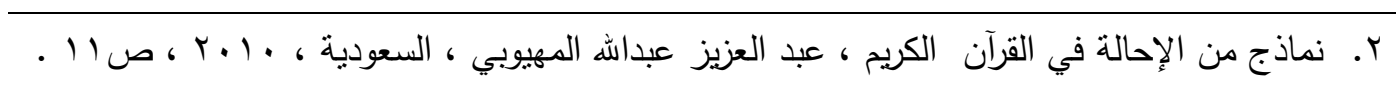

r. الصور الأحالية في سورة (ق) وأثزها في توجيه المعنى ، حسين عودة هاشم ، مجلة ميسان للاراسات

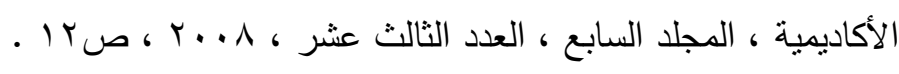

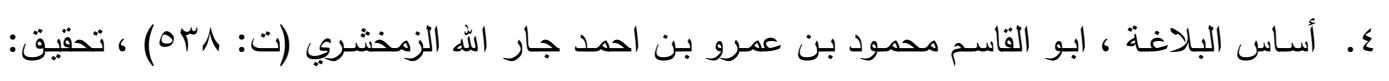

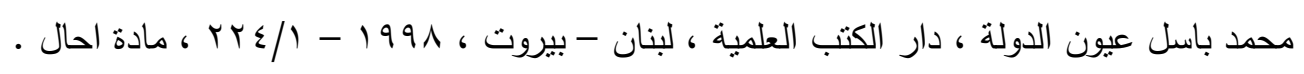

$$
\text { ه. سورة الكهف / الآية (1 • (1) . }
$$

7. غريب الحديث ، حمد بن محمد بن ابراهيم الخطابي ، جامعة ام القرى ، مكة المكرمة ، ب · ع هـ 109

V. النهاية في غريب الحديث والاثر ، ابو السعادات المبارك بن محمد الجزري ، تحقيق: طاهر احمد

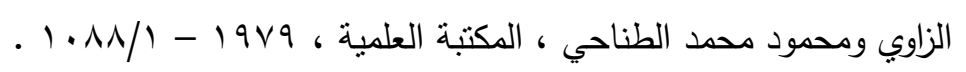

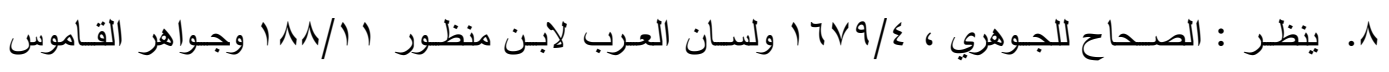

$$
.1 \vee 9 / 1 \leq
$$

9 9. لسان العرب لابن منظور ، 119/11 ، مادة احال .

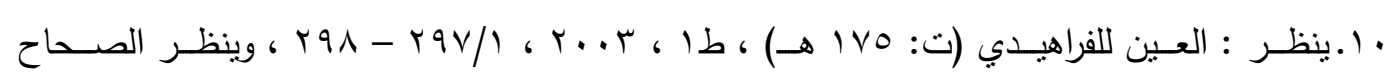

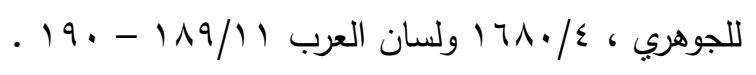

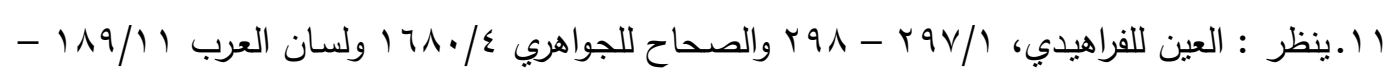

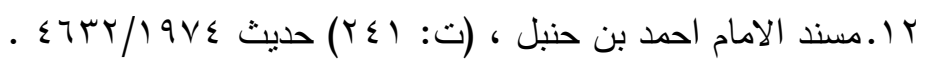

ب ا ـمعجم اللسانيات الحديثة ، سامي حنا ، ص .0. . 
ع ا ـ الإحالة واثرها في تماسك النص في القصص القرآنية ، انس بن محمود بن يوسف ، اليمن ، 9 . . Y ،

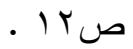

1. إعجاز القرآن والبلاغة النبوية ، مصطفى صـادق الرافعي ، دار الكتاب العربي ، بيروت - لبنان ،

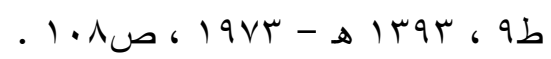

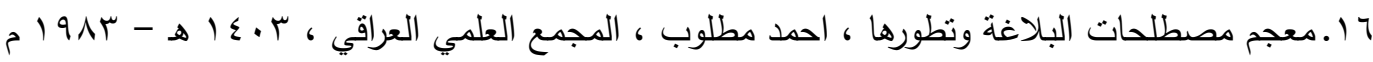

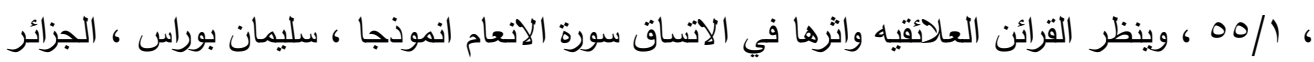

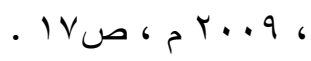

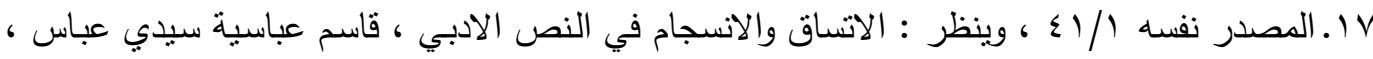

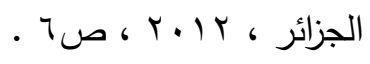

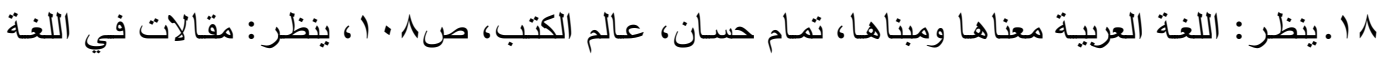

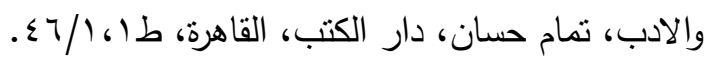

$$
\begin{aligned}
& 9 \text { 1. الخلاصة النحوية، تمام حسان، عالم الكتب، القاهرة، طا، . . بrم، ص9؟. }
\end{aligned}
$$

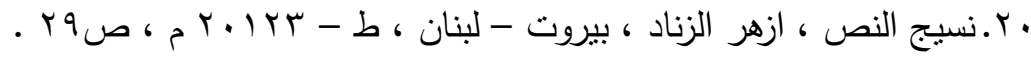

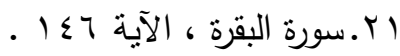

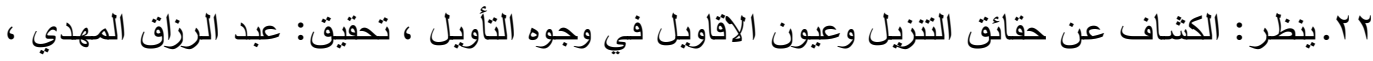

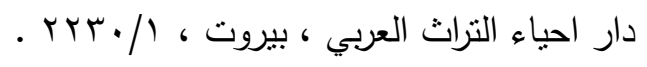

r r.نحو نظرية عربية للإحالة الضميرية ، ميلود نزار ، ( ب ، صسا . .

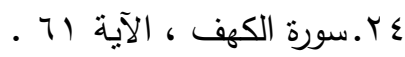




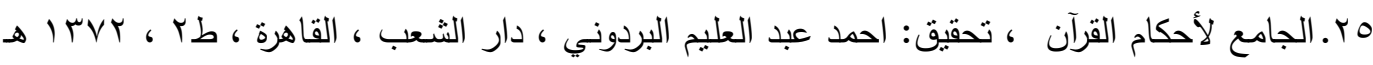
$.12 / 11$ 。

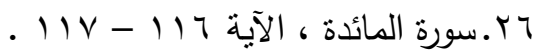

Vحمد بن يوسف الثهير بابي حسين الاندلسي (ت: V V هـ) ، تحقيق: عادل احمد عبد الموجود

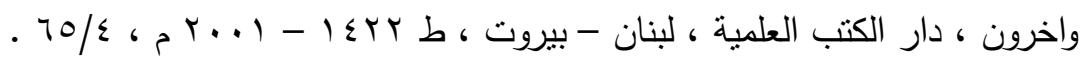

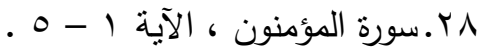

9r. عود الضمير بين اللسانيات الحديثة والنحو العربي ( استراتيجية الإحالة ) 9 . ب م ، ص. . .

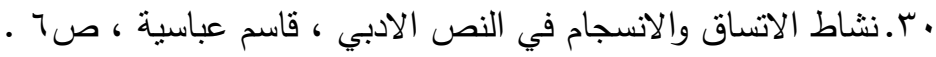
آس. عود الضمير بين اللسانيات الحديثة والنحو العربي ، ص. 1 . بr.ينظر : نسيج النص ، الازهر الزناد ،ص11119 119 ـ

rTr. علم اللغة النص بين النظرية والنطبيق ، صبحي ابراهيم الفقي ، دار الضياء ، القاهرة ، طا ، 1... . $\leqslant 0 / 1 \cdot$ a

ع ז.ينظر : مهارات التعرف على الترابط في النص ، ريما الجرف ، مجلة رسالة الخليج العربي ، العدد V ،

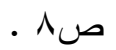

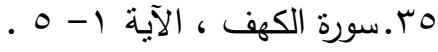

باس.عود الضمير بين اللسانيات الحديثة والنحو العربي ، ص 11 .

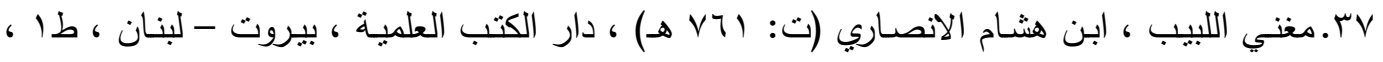

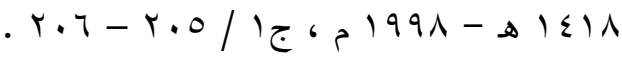




\section{مجلــــة كليـــة التزبيـــة}

مب.سورة الاخلاص ، الآية ا .

وץ.سورة المائدة ، الآية بس .

• ع.في ظلال القرآن سيد قطب ، 0/ • 1 1 . .

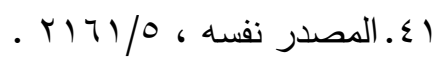

بـ ـ المهائمي علي بن احمد المهائمي الهندي ، ابي الحسن المعروف بالمخدوم ، باحث مفسر ، كان يقول

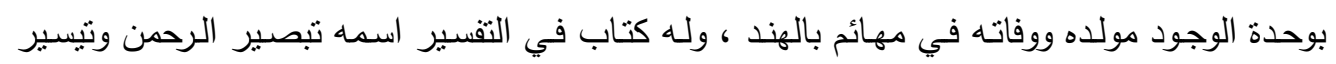

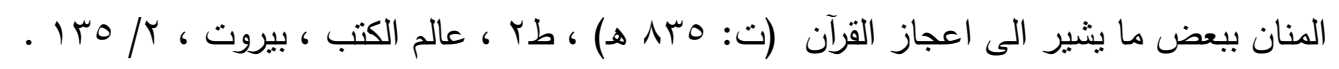

بع.تبصير الرحمن وتيسير المنان للمهايمي علي بن احمد بن ابراهيم ، ت: هب هـ ، ينظر : طبقات

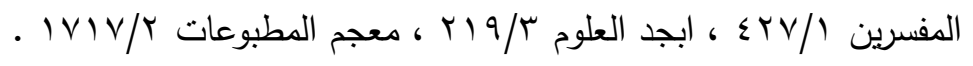

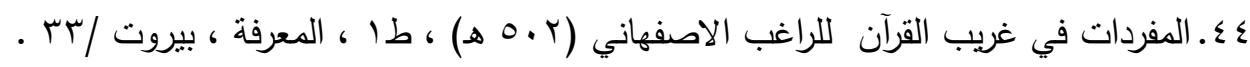

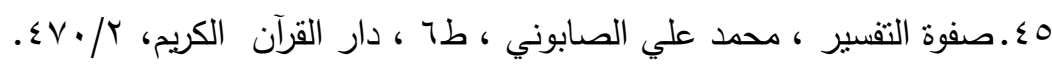

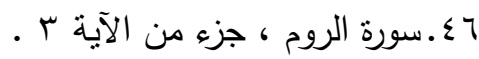

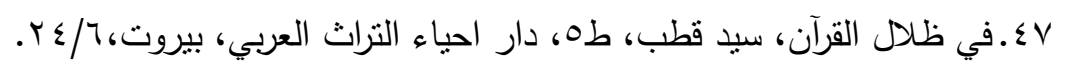

^ـ ـ الاساس في التقسير ، سعيد حوى ، الناشر دار السلام للطباعة والنشر والتوزيع لصاحبها عبد القادر

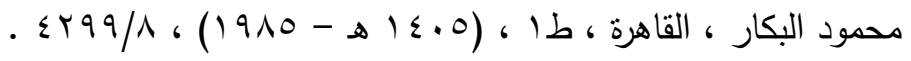

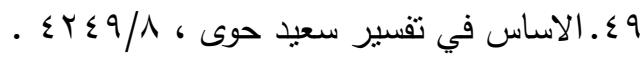

• ه. التفسير المنير في العقيدة والثريعة والمنهج للأستاذ الدكتور وهبة الزحيلي رئيس قسم الفقه الاسـامي ومذاهبه في جامعة دمشق ، طا ، دار الفكر المعاصر ، بيروت ، اب/عء . 


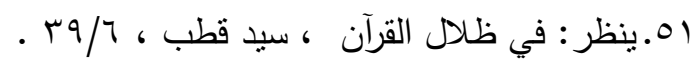

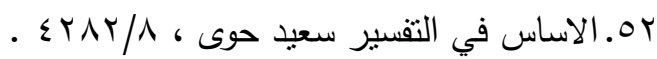

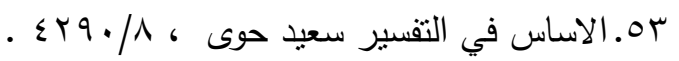

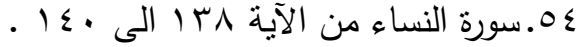

00.سورة الروم ، من الآية ـ الى سا .

07.في ظلال القرآن ، سبد قطب ، 10/. FVT .

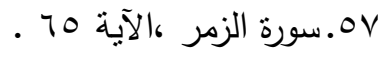

$$
\text { هـ.سورة الروم ، الآية وج - . . . }
$$

0. في ظلال القرآن ، سيد قطب ، جه ، ص1YYT .

• T. في ظلال القرآن ، سيد قطب ، YVTN/0 .

الج.سورة الروم ، الآية . . .

با7.سورة الروم ، الآية 919

ب7.سورة الانعام ، الآية بr TI .

ع 7.سورة الروم ، الآية اب .

7. تقسير القرآن لابن كثير ن س/ع اء .

77.سورة الكهف ، الآية (1) . 


\section{قائمة المسادر والمراجع :}

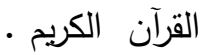

1. الاتساق والانسجام في النص الادبي، قاسم عباسية، سيدي لعباس، الجزائر، ب ا • بم.

r. الإحالة واثرها في تماسك النص في القصص القرآني ، انس بن محمود بن يوسف ، اليمن .

r. اساس البلاغة ، ابو القاسم محمود بن عمرو بن احمد جار الله الزمخشري (ت: ^به هـ) ، تحقيق:

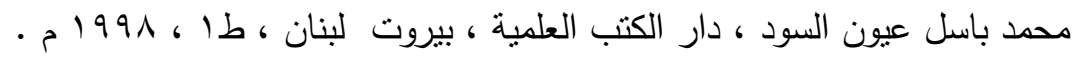

ء. اسباب نزول القرآن ، ابي الحسن علي بن احمد الواحدي (ت: 7^؛ هـ) ، تحيقي: كمال بسيوني

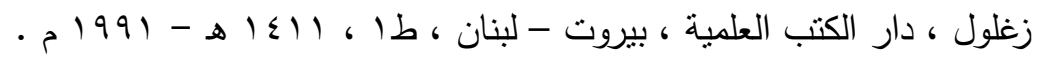

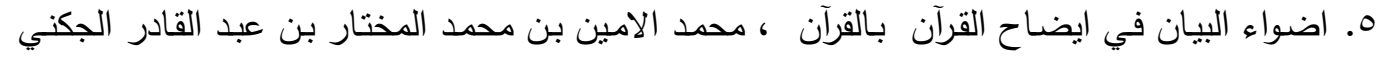

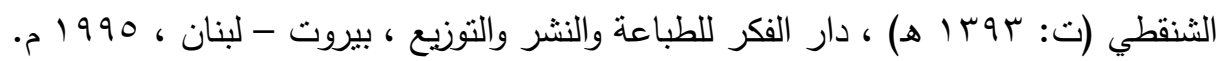

ז. اعجاز القرآن والبلاغة النبوية ، مصطفى صادق الرافعي ، دار الكتاب العربي ، بيروت - لبنان ، ط

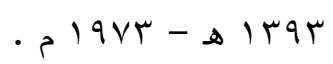

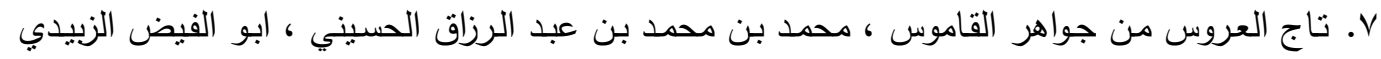

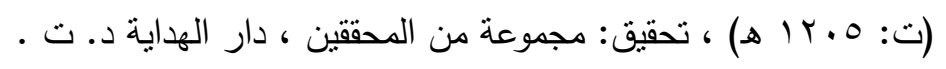

^. التحرير والتتوير، محمد الظاهر بن عاثشور، الدار التونسية للنشر ، تونس، ع191 م .

$$
\text { 9. تيسير المنان للمهايمي علي بن احمد (ت: هبم ) بيروت - لبنان • }
$$$$
\text { • 1. تبصير الرحمن، المهايمي علي بن احمد (ت: Oبم هـ) ، بيروت - لبنان. }
$$ 
ال. التفسير المنير في العقيدة والثريعة والمنهج ، وهبة الزحلي ، بيروت - لبنان ، ب99 1 م .

ז ا. الجامع لاحكام القرآن ، ابو عبداله محمد بن احمد بن ابي بكر بن فرج الانصـاري الخزرجي ، شمس الدين القرطبي ، (ت: (7VI هـ) ، تحقيق: هثام سمير البخاري ، دار عالم الكتب ، الرياض ،

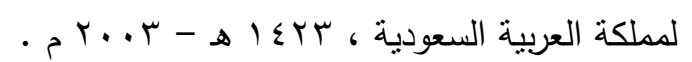

با.. جواهر القاموس ، ابو عبداله ، دار الكتب للطباعة والنشر والاعلان ، بيروت - لبنان ، 1997 ع ا. الصحاح تاج اللغة وصحاح العربية ، اسماعيل بن حماد الجوهري ، تحقيق: احمد عبد الغفور عطار ، دار العلم للملايين ، .99 19 م .

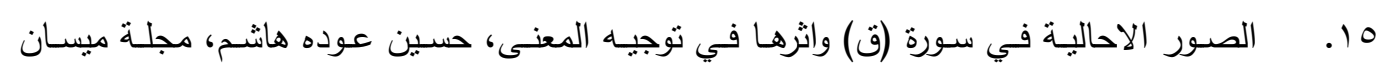

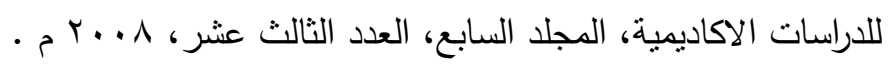

جا ـ الصحاح للجواهري تاج اللغة وصحاح اللغة العربية ، اسماعيل بن حماد الجوهري ، تحقيق: عبد الغفور عطار ، الناشر دار الكتاب العربي ، مصر .

VI. العين ، الخليل بن احمد الفراهيدي (ت: 1V0 هـ) ، المحقق عبد الحميد هنداوي ، دار الكتب

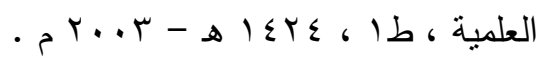

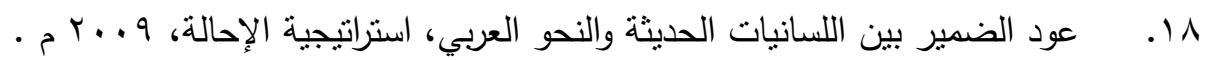

9 1. . علم اللغة النص بين النظرية والتطبيق ، صبحي ابراهيم الفقي ، دار الضياء ، القاهرة ، طا ، . 21997

• ·. غريب الحديث ، حمد بـن محمد بن ابراهيم الخطابي ، جامعـة امـن القرى ، مكـة المكرمـة ، $\cdot r+1$ 


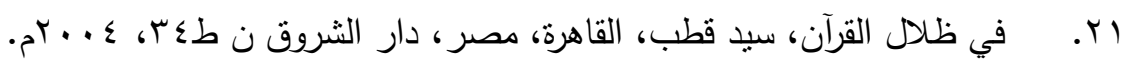

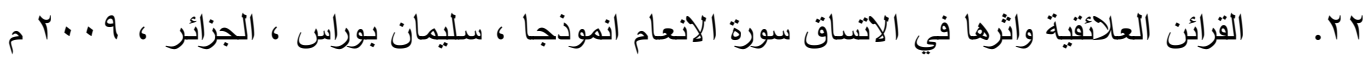

بr. . الكثـاف عن حقائق التنزيـل وعيون الاقاويـل في وجـوه التاويـل ، ابو القاسـ محمـود بـن عمر الزمخثري ، تحقيق: عبد الرزاق المهدي ، دار احياء التراث العربي ، بيروت . ع r. اللغة العربية معناها ومبناها ، تمام حسان ، عالم الكتب ، القاهرة ، د ت .

ه广. لسـان العـرب ، جمـال الـدين ابسي الفضـل محمد بـن مكرم ابـن منظور (ت: VII هـ) ، دار

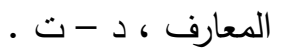

צr. مسند الامام احمد ، احمد بن حنبل ابو عبداله الثيبياني (ت: IకY هـ) ، مؤسسة قرطبة ، مصر

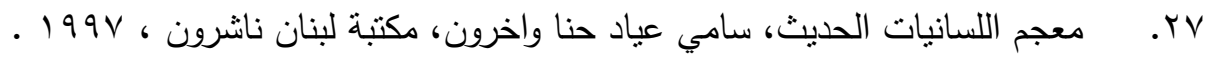

^ץ. معجم المصطلحات البلاغية وتطورها ، احمد مطلوب ، المجمع العلمي العراقي ، ب. ع ا هـ $\cdot$. $191 \mathrm{r}$

q.r. مهارات التصرف، ابو عبداله، دار الكتب العلمية للنشر والاعلان والتوزيع.

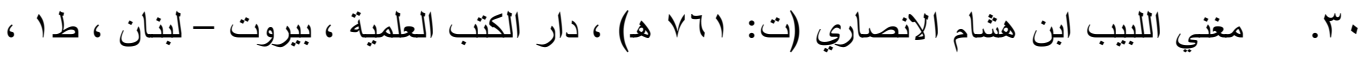

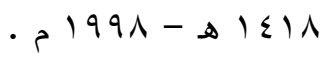

اس. مهارات التصرف على الترابط في النص ، ريما الجرف ، مجلة رسالة الخليج العربي ، العدد V •

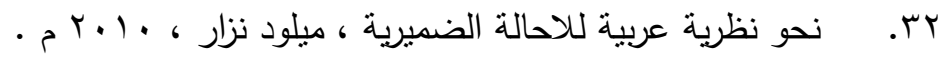




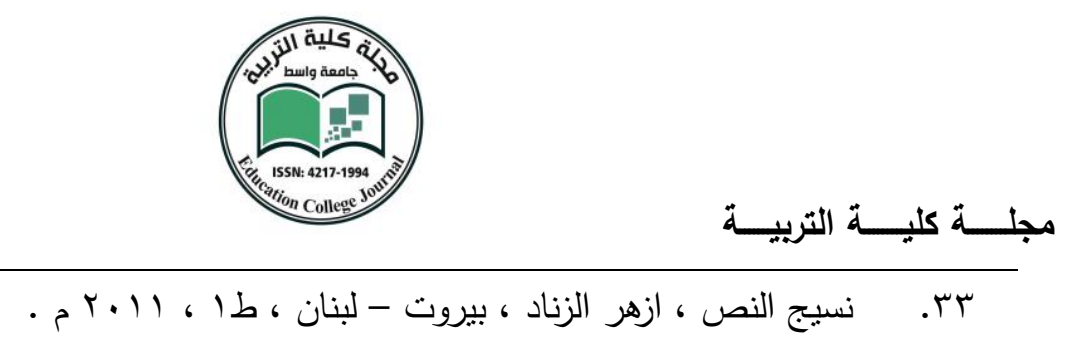

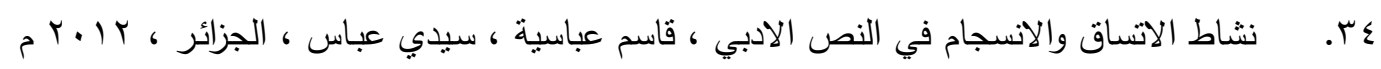

هب. نماذج من الإحالة في القرآن الكريم ، عبد العزبز عبداله المهيوبي ، الرباض - السعودية ، $\cdot r \cdot 1 \cdot$

بس. النهايـة في غريب الحديث والاثر ، ابو السعادات المبارك بن محمد الجزري ، تحقيق: طاهر

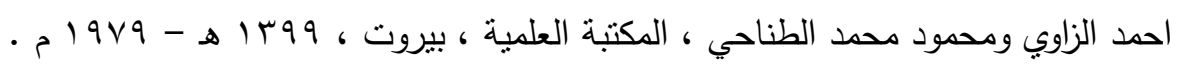

